\title{
Early prediction of renal graft function: Analysis of a multi-centre, multi-level data set
}

\author{
Arturo Blazquez-Navarro ${ }^{1,2,3}$, Chris Bauer ${ }^{4}$, Nicole Wittenbrink ${ }^{1,2}$, Kerstin Wolk $^{2,5}$, Robert Sabat ${ }^{5,6}$, Chantip \\ Dang-Heine ${ }^{2,7}$, Sindy Neumann ${ }^{8}$, Toralf Roch ${ }^{2,3}$, Patrizia Wehler $^{2,3}$, Rodrigo Blazquez-Navarro $^{1}$, Sven Olek $^{9}$, \\ Oliver Thomusch ${ }^{10}$, Harald Seitz $^{11}$, Petra Reinke ${ }^{2,12}$, Christian Hugo $^{13}$, Birgit Sawitzki ${ }^{2}$, Nina Babel ${ }^{2,3} * \dagger$, Michal \\ Or-Guil ${ }^{1,14 * \dagger}$ \\ ${ }^{1}$ Systems Immunology Lab, Department of Biology, Humboldt-Universität zu Berlin: Philippstr. 13, 10115 Berlin, Germany. \\ ${ }^{2}$ Berlin Institute of Health Center for Regenerative Therapies (BCRT): Berlin-Brandenburger Centrum für Regenerative \\ Therapien, Charité - Universitätsmedizin Berlin, Augustenburger Platz 1, 13353 Berlin, Germany. \\ ${ }^{3}$ Center for Translational Medicine, Universitätsklinikum der Ruhr-Universität Bochum, Medizinische Klinik I: \\ Hölkeskampring 40, 44625 Herne, Germany. \\ ${ }^{4}$ MicroDiscovery GmbH: Marienburger Str. 1, 10405 Berlin Germany. \\ ${ }^{5}$ Psoriasis Research and Treatment Center, Institute of Medical Immunology/Department of Dermatology and Allergy, \\ Charité - Universitätsmedizin Berlin: Charitéplatz 1, 10117 Berlin, Germany. \\ ${ }^{6}$ Interdisciplinary Group of Molecular Immunopathology, Institute of Medical Immunology/Department of Dermatology and \\ Allergy, Charité - Universitätsmedizin Berlin: Charitéplatz, 1, 10117 Berlin, Germany. \\ ${ }^{7}$ Clinical Study Center (CSC), Berlin Institute of Health, and Charité - Universitätsmedizin Berlin, Corporate Member of \\ Freie Universität Berlin, Humboldt-Universität Zu Berlin, Campus Charité Mitte, Berlin, Germany. \\ 8numares AG: Am Biopark 9, 93053 Regensburg, Germany. \\ ${ }^{9}$ Ivana Türbachova Laboratory for Epigenetics, Epiontis GmbH, Precision for Medicine Group: Barbara-McClintock-Straße \\ 6, 12489 Berlin, Germany \\ ${ }^{10}$ Klinik für Allgemein- und Viszeralchirurgie, Universitätsklinikum Freiburg: Hugstetter Straße 55, 79106 Freiburg, \\ Germany. \\ ${ }^{11}$ Fraunhofer Institute for Cell Therapy and Immunology, Bioanalytics und Bioprocesses: Am Mühlenberg 13 \\ 14476 Potsdam-Golm, Germany \\ ${ }^{12}$ Berlin Center for Advanced Therapies (BeCAT), Charité - Universitätsmedizin Berlin: Augustenburger Platz 1, 13353 \\ Berlin, Germany. \\ ${ }^{13}$ Universitätsklinikum Carl Gustav Carus, Medizinische Klinik III - Bereich Nephrologie: Fetscherstraße 74, 01307 \\ Dresden, Germany. \\ ${ }^{14}$ Institute of Medical Immunology, Charité - Universitätsmedizin Berlin: Charitéplatz 1, 10117 Berlin, Germany. \\ * Equal contribution $\uparrow$ Corresponding authors \\ Word count: 3692 words
}

NOTE: This preprint reports new research that has not been certified by peer review and should not be used to guide clinical practice. 


\section{ABSTRACT}

\section{Introduction}

Long-term graft survival rates after renal transplantation are still moderate. We aimed to build an early predictor of an established long-term outcomes marker, the glomerular filtration rate (eGFR) one year post-transplant (eGFR-1y).

\section{Materials and Methods}

A large cohort of 376 patients was characterized for a multi-level bio-marker panel including gene expression, cytokines, metabolomics and antibody reactivity profiles. Almost one thousand samples from the pre-transplant and early post-transplant period were analysed. Machine learning-based predictors were built employing stacked generalization.

\section{Results}

Pre-transplant data led to a prediction achieving a Pearson's correlation coefficient of $\mathrm{r}=0.39$ between measured and predicted eGFR-1y. Two weeks post-transplant, the correlation was improved to $r=0.63$, and at the third month, to $r=0.76$. eGFR values were remarkably stable throughout the first year post-transplant and were the best estimators of eGFR-1y already two weeks post-transplant. Several markers were associated with eGFR: The cytokine stem cell factor demonstrated a strong negative correlation; and a subset of 19 NMR bins of the urine metabolome data was shown to have potential applications in non-invasive eGFR monitoring. Importantly, we identified the expression of the genes TMEM176B and HMMR as potential prognostic markers for changes in the eGFR. 
medRxiv preprint doi: https://doi.org/10.1101/2021.01.04.20248473; this version posted January 5, 2021. The copyright holder for this preprint

(which was not certified by peer review) is the author/funder, who has granted medRxiv a license to display the preprint in perpetuity.

All rights reserved. No reuse allowed without permission.

\section{Discussion}

Our multi-centre, multi-level data set represents a milestone in the efforts to predict transplant outcome. While an acceptable predictive capacity was achieved, we are still very far from predicting changes in the eGFR precisely. Further studies employing further marker panels are needed in order to establish predictors of eGFR-1y for clinical application; herein, gene expression markers seem to hold the most promise. 


\section{INTRODUCTION}

Long-term outcomes of renal transplantation are still disappointing, with a median graft survival time of around ten years.[1,2] Currently, a large effort is being undertaken to determine new risk factors for the outcome of renal transplantation in order to improve therapy and organ allocation.[3-6] While a number of risk factors have been identified (including HLA mismatch, age of donor or cold ischemia time), they are still not sufficient for a precise prediction of transplant outcome.[3,4,6-8] Therefore, machine learning-based risk assessment models are envisaged to assist medical decision-making in patient therapy and eventually improve patient care.[9]

The most commonly used end-point for risk assessment models is the incidence of acute rejection.[10-14] However, acute rejection occurs rather infrequently in renal transplantation and treatments against acute rejection are reasonably effective.[1,15-17] The estimated Glomerular Filtration Rate (eGFR) could therefore offer a more appropriate end-point.[6] In fact, the eGFR one year post-transplant (eGFR-1y) is an accepted marker of long-term transplant outcome.[18-20] eGFR is an estimate of renal function calculated based on the concentration of serum creatinine and demographic characteristics of the patient; it results from the combined influence of all individual risk factors. $[8,21]$ This is the reason why complex predictive markers are needed - we cannot expect that only one marker will predict eGFR-1y. However, to our knowledge there exists still no predictive model of eGFR with a sufficient predictive performance for the clinic.

The goal of this work is to develop a predictive model for the eGFR-1y employing data collected in the pre-transplant and early post-transplant period. Furthermore, we aimed to identify and characterize potential novel markers of the renal function. For this, we have 
acquired a multi-level biomarker panel with an eminent immunological focus. Importantly, the choice of markers was not based on an explorative multi-omics approach but rather on data known for their mechanistic connection to transplant outcome. The markers used here were already identified as useful in previous studies addressing immunological risk factors of acute transplant rejection.[22-28]

The analysis was performed according to the following strategy: First, predictive models of eGFR-1y were calculated for each marker subset and visit. Second, predictive models were combined to provide a final prediction of eGFR-1y. Third, the individual markers of the best predictors were investigated in detail, especially to find out whether these markers were diagnostic (reflecting the renal function at the time of sampling), or prognostic (predicting future changes of the renal function). Finally, a second predictive model was built, using exclusively prognostic markers.

\section{MATERIALS AND METHODS}

\section{Patient population and monitoring}

We characterized the patient cohort of the randomized, multi-centre Harmony trial (NCT 00724022) for a biomarker panel as part of the e:KID study.[17] Inclusion criteria were the availability of follow-up data for eGFR-1y, and for at least one of the three study visits. The study was carried out in compliance with the Declaration of Helsinki and Good Clinical Practice. The trial was approved by the Ethics Committee of the Gustav Carus Technical University Dresden.

As published before, the patients of the patient cohort were treated with a quadruple (arm A) or triple (arms B and C) immunosuppressive therapy.[17] Shortly, arm A received a 
medRxiv preprint doi: https://doi.org/10.1101/2021.01.04.20248473; this version posted January 5, 2021. The copyright holder for this preprint (which was not certified by peer review) is the author/funder, who has granted medRxiv a license to display the preprint in perpetuity.

All rights reserved. No reuse allowed without permission.

basiliximab induction therapy and maintenance therapy consisting of tacrolimus (Advagraf®, Astellas), mycophenolate mofetil (MMF) and corticosteroids. Arm B received the same induction and maintenance therapy, with corticosteroids withdrawn at day 8 post-transplant. Finally, induction therapy for arm C consisted of rabbit anti-thymocyte globulin (ATG), with the same maintenance therapy as arm B. Furthermore, based on their risk constellation patients received an anti-cytomegalovirus prophylaxis consisting of valganciclovir.[29]

Patients were monitored for eGFR during the first post-transplant year, calculated using the CKD-EPI formula and measured in $\mathrm{mL} \cdot \mathrm{min}^{-1} \cdot 1.73 \mathrm{~m}^{-2} \cdot[21] \mathrm{eGFR}$ was assessed at regular intervals: 2nd week, 1st month, 2nd month, 3rd month, 6th month, 9th month, and 12th month post-transplant.

\section{Characterization of the patient cohort by a biomarker panel}

The patients were characterized by a biomarker panel consisting of five marker subsets (Table 1) at three visits: pre-transplant (pre-Tx), two weeks post-transplant (2w) and three months post-transplant $(3 \mathrm{~m})$. For a detailed description of the methods employed in the characterization, see the Supplementary Methods.

Shortly, the cytokine concentration levels were measured by ELISA. Gene expression markers were selected based on their role in operational tolerance or rejection and measured employing TaqMan Gene Expression Assays (Thermo Fisher Scientific).[25-28] Serum antibodies (SAB) were screened employing HLA-1 mixed antigen bead assay; the raw mean fluorescence intensity for each bead was employed for prediction.[10] The urinary metabolomics spectrum was determined employing nuclear magnetic resonance (NMR), which was binned and normalized to facilitate the analysis. Finally, while viral loads were monitored by qPCR as described before, other clinical data were measured de-centrally and provided by the transplantation centres.[30] 


\begin{tabular}{|c|c|c|c|c|}
\hline Sample type & Marker type & Markers & $\begin{array}{l}\text { No. of } \\
\text { markers }\end{array}$ & Name of subset \\
\hline Serum & $\begin{array}{l}\text { Cytokine } \\
\text { concentration }\end{array}$ & $\begin{array}{l}\text { Interleukin } 19 \text { (IL-19), Interleukin } \\
22 \text { (IL-22), stem cell factor (SCF), } \\
\text { soluble suppression of } \\
\text { tumorigenicity } 2 \text { (sST2), Beta- } \\
\text { defensin } 2 \text { (BD2), angiogenin and } \\
\text { endostatin }\end{array}$ & 7 & Cytokines \\
\hline Whole blood & $\begin{array}{l}\text { Gene expression of } \\
\text { tolerance and } \\
\text { rejection markers }\end{array}$ & $\begin{array}{l}\text { CD79B, CD200, CD247, CD274, } \\
\text { CXCL10, FCRL1, FCRL2, FOXP3, } \\
\text { HMMR, HS3ST1, LAG3, } \\
\text { MAN1A1, MS4A1, NAV3, PNOC, } \\
\text { SH2D1B, SLC8A1, TCL1A, TLR5 } \\
\text { and TMEM176B }\end{array}$ & 20 & Gene expression \\
\hline Urine & $\begin{array}{l}\text { Metabolomic } \\
\text { parameters (given as } \\
\text { intensities) }\end{array}$ & Spectral regions & 377 & Metabolome \\
\hline Serum & $\begin{array}{l}\text { Single antigen } \\
\text { reactivity profile }\end{array}$ & A subset of HLA-1 allotypes & 97 & SAB \\
\hline Various & $\begin{array}{l}\text { Demographic and } \\
\text { clinical characteristics }\end{array}$ & $\begin{array}{l}\text { Demographics of recipient (age, } \\
\text { weight, sex, BMI and underlying } \\
\text { renal disease), donor characteristics } \\
\text { (donor age, last measured creatinine, } \\
\text { donor type and expanded criteria } \\
\text { donor), panel reactive antibodies, } \\
\text { previous transplants, cold ischemia }\end{array}$ & 56 & Clinical \\
\hline
\end{tabular}




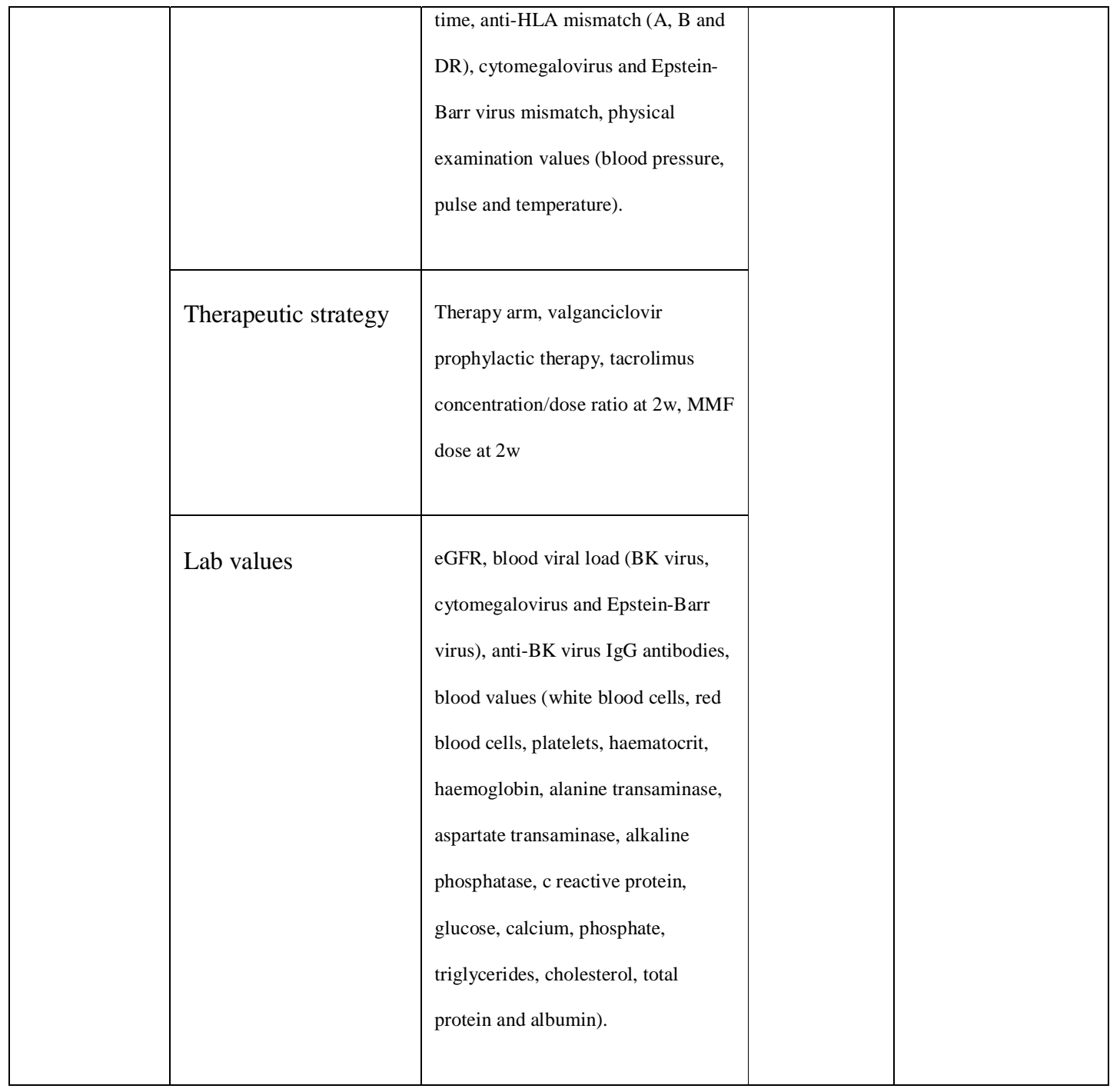

Table 1. Description of the five subsets of the biomarker panel of the e:KID study. The number and list of the markers corresponds to those with a data availability such that they could be employed for prediction for at least one visit (for more details see Statistical analysis: Prediction of eGFR). For the definition of the gene expression subset abbreviations, see the Supplementary Methods.

\section{Statistical analysis: Descriptive statistics}

Categorical variables are summarised here as numbers and frequencies; quantitative variables are reported as median and interquartile range (IQR). Box plots depict the median, first and 
medRxiv preprint doi: https://doi.org/10.1101/2021.01.04.20248473; this version posted January 5, 2021. The copyright holder for this preprint (which was not certified by peer review) is the author/funder, who has granted medRxiv a license to display the preprint in perpetuity.

All rights reserved. No reuse allowed without permission.

third quartile of a variable; the maximum length of the whiskers corresponds to 1.5 times the IQR. Correlations of two continuous variables were calculated employing Pearson's correlation coefficient $r$. For the visual representation of linear relationships between variables, the regression line and the confidence interval were calculated employing Deming regression; the $95 \%$ confidence interval is shown as a shaded grey area.

All statistical and modelling analyses were performed employing R (Version 3.6.1).[31]

\section{Statistical analysis: Prediction of eGFR}

Prediction of eGFR-1y was performed employing the method of stacked generalization, which aims to combine several weak predictors to produce a precise final predictive model.[32] Reason for this was the differences in data availability patterns between the single subsets, as few patients had available data for all subsets for a given time point. Thus, a predictor was created for each visit and each one of the five marker subsets.

The marker subsets were employed for the prediction as follows: For each visit and marker subset, only markers with $<20 \%$ missing values were taken into account. This percentage was calculated considering only the patients (partially) characterized for the marker subset at hand, not the entire cohort. Missing values were imputed employing the R package mice (Version 3.8.0) with the method "classification and regression trees" for multiple imputation with 5 multiple imputations and 50 iterations.[33]

Prediction of eGFR-1y was performed employing elastic net regression (R package glmnet, Version 3.0-2) with cross-validation.[34] The elastic net regression was performed with eGFR-1y as the dependent variable and the marker subset (as defined above) as independent variables. Importantly, elastic net regression performs variable based on its parameters alpha and lambda, so that only part of the measured markers are employed for prediction. To avoid 
overfitting, the elastic net regression was nested in a leave-p-out cross validation $(p=5)$; thus, each iteration of the elastic net regression was optimized on a training set of $n-5$ patients (where $\mathrm{n}$ is the number of the patients in the subset) and calculated for 5 patients. The values of the elastic net parameters alpha and lambda were optimized for each training set employing the function cva.glmnet (R package glmnetUtils, Version 1.1.5), with 10 crossvalidation folds.[35] The vector of possible values for alpha was defined as the cubic potency of an arithmetic progression between 0 and 1 , with a common difference of 0.1 . The value of the parameters for each training set was set to the combination of alpha and lambda achieving the minimum cross-validated mean error in the training set (alpha.min and lambda.min). The resulting model for each training set was employed for the prediction of eGFR-1y of the corresponding test set. The performance of the predictor was assessed employing the Pearson's $r$ of the correlation between measured and predicted eGFR-1y.

The final prediction of eGFR-1y for each visit was estimated considering all predictors that achieved $r>0.15$. This final prediction was calculated for each individual patient as a weighted mean of all the available predictions; the weighs were defined as the estimated Pearson's correlation coefficient $\mathrm{r}$ for each predictor. Importantly, no imputation was performed in this step, so that for each single patient only available predictors were employed. The quality of the final prediction for each of the visits was likewise assessed employing Pearson's correlation coefficient $r$.

\section{Statistical analysis: Selection of important markers and}

\section{identification of prognostic markers}

The selection of markers important for the eGFR-1y prediction from each marker subset was based on the internal variable selection of elastic net regression. In the case of the 
medRxiv preprint doi: https://doi.org/10.1101/2021.01.04.20248473; this version posted January 5, 2021. The copyright holder for this preprint (which was not certified by peer review) is the author/funder, who has granted medRxiv a license to display the preprint in perpetuity.

All rights reserved. No reuse allowed without permission.

metabolome prediction, due to the high number of markers, variable selection was performed with a different optimization of lambda. Thus, the value of lambda leading to the most regularized model within one standard error of the minimum cross-validated mean error (lambda.1se) was employed for variable selection of the metabolome predictor (but not for calculation of eGFR-1y). The importance of a marker was defined as the percentage of crossvalidation iterations for which the marker was selected in the regression. A predictor achieving an importance of $100 \%$ was considered to be important for the prediction.

To compare the performance of two different predictors of eGFR, the differences in the absolute error of each prediction were tested employing the paired samples Wilcoxon signed rank test.

To determine whether a set of markers was prognostic - i.e. associated with eGFR-1y independently of the eGFR at the time of sampling - a multiple linear regression analysis was employed. Thus, the regression model incorporated eGFR-1y as dependent variable and the variable(s) of interest and the eGFR at the time of sampling (eGFR-2w or eGFR-3m) as independent variables. The $\mathrm{P}$ values for the independent variables of the regression model were calculated employing the $t$ test. Variables achieving a $\mathrm{P}$ value below 0.050 were considered to be prognostic for eGFR-1y independently from eGFR at the time of sampling, therefore providing an added value for the prediction of eGFR-1y.

\section{RESULTS}

\section{Characteristics of the patient cohort}

Out of 540 patients, a total of $376(69.6 \%)$ patients from 14 transplant centres were characterized. A total of 958 samples were measured. The characteristics of the patient cohort 
are presented in Table 2; eGFR dynamics during the follow-up are depicted in Figure 1. An overview of the samples characterized for each marker subset is provided in Table 3. Importantly, the patient cohort $(\mathrm{N}=376)$ had significantly higher eGFR at $2 \mathrm{w}$ than the Harmony patients lost to follow-up $(\mathrm{N}=164)\left(35.5\right.$ [19.9-47.6] vs. 25.6 [12.2-39.8] $\mathrm{mL} \cdot \mathrm{min}^{-}$ $\left.{ }^{1} \cdot 1.73 \mathrm{~m}^{-2} ; \mathrm{P}<0.001\right)$.

\begin{tabular}{|c|c|c|}
\hline Variable & Variable type & Cohort $(\mathrm{N}=376)$ \\
\hline Sex: Female & Categorical & $130(34.6 \%)$ \\
\hline Age at pre-Tx (years) & Quantitative & 55 [44-62] \\
\hline Weight at pre-Tx (kg) & Quantitative & $77.3[68.2-88.8]$ \\
\hline BMI at pre-Tx $\left(\mathrm{kg} \cdot \mathrm{m}^{-2}\right)$ & Quantitative & $25.8[23.1-28.8]$ \\
\hline $\begin{array}{l}\text { Patient with no previous } \\
\text { transplant }\end{array}$ & Categorical & $361(96 \%)$ \\
\hline Living donor & Categorical & $55(14.6 \%)$ \\
\hline Age of donor (years) & Quantitative & 53 [44-63] \\
\hline
\end{tabular}




\begin{tabular}{|c|c|c|c|}
\hline \multicolumn{2}{|c|}{ Expanded criteria donor* } & Categorical & $150(39.9 \%)$ \\
\hline \multicolumn{2}{|c|}{ Total HLA mismatches } & Quantitative & $3[2-4]$ \\
\hline \multicolumn{2}{|c|}{ Cold ischemia time (min) } & Quantitative & 616 [413-840] \\
\hline \multirow[t]{3}{*}{$\begin{array}{l}\text { Immunosup } \\
\text { pression } \\
\text { therapy arm }\end{array}$} & $\begin{array}{l}\text { Arm A } \\
\text { (basiliximab } \\
+ \text { MMF + } \\
\text { tacrolimus + } \\
\text { corticosteroid } \\
\text { s) }\end{array}$ & Categorical & $139(37.0 \%)$ \\
\hline & $\begin{array}{l}\text { Arm B } \\
\text { (basiliximab } \\
\text { + MMF + } \\
\text { tacrolimus) }\end{array}$ & Categorical & $125(33.2 \%)$ \\
\hline & $\begin{array}{l}\text { Arm C (ATG } \\
+ \text { MMF + } \\
\text { tacrolimus) }\end{array}$ & Categorical & $112(29.8 \%)$ \\
\hline
\end{tabular}




\begin{tabular}{|c|c|c|}
\hline $\begin{array}{l}\text { Usage of anti- } \\
\text { cytomegalovirus } \\
\text { prophylaxis }\end{array}$ & Categorical & $216(57.4 \%)$ \\
\hline Incidence of acute rejection & Categorical & $38(10.1 \%)$ \\
\hline $\begin{array}{l}\text { Incidence of severe } B K \text { virus } \\
\text { viremia }\left(>10,000 \text { copies } \cdot \mathrm{mL}^{-}\right. \\
\left.{ }^{1}\right)\end{array}$ & Categorical & $47(12.5 \%)$ \\
\hline $\begin{array}{l}\text { Incidence of severe } \\
\text { cytomegalovirus viremia } \\
\left(>10,000 \text { copies } \cdot \mathrm{mL}^{-1}\right)\end{array}$ & Categorical & $17(4.5 \%)$ \\
\hline GFR-2w $\left(\mathrm{mL} \cdot \mathrm{min}^{-1} \cdot 1.73 \mathrm{~m}^{-2}\right)$ & Quantitative & $34.5[19.9-47.6]$ \\
\hline GFR-1y $\left(\mathrm{mL} \cdot \mathrm{min}^{-1} \cdot 1.73 \mathrm{~m}^{-2}\right)$ & Quantitative & $47.6[35.0-60.8]$ \\
\hline
\end{tabular}

Table 2. Characteristics of the patient cohort, including demographics, treatment and transplant outcome. Categorical variables are shown as count (\% frequency), continuous variables as median [IQR]. *The expanded criteria comprise a donor age greater than 60 years, or an age greater than 50 years combined with at least two of the following factors: 
cerebrovascular accident as the cause of death, hypertension, or a serum creatinine level of more than $1.5 \mathrm{mg} \cdot \mathrm{dL}^{-1} \cdot[17]$

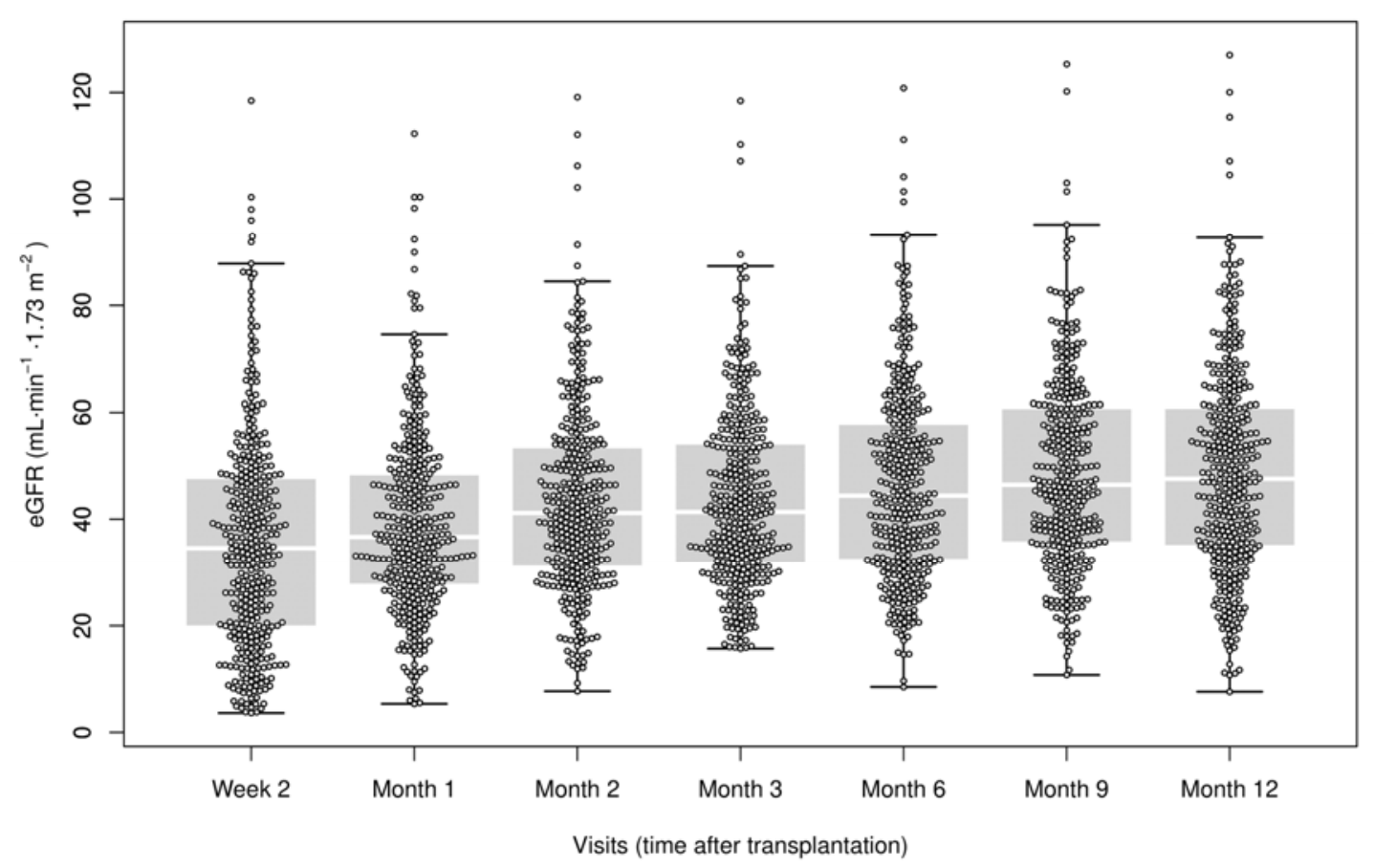

Figure 1. eGFR dynamics in the patient cohort.

\begin{tabular}{|c|c|c|c|c|c|c|}
\hline \multirow{2}{*}{ Visits } & \multicolumn{5}{|c|}{ Number of samples for prediction } \\
\cline { 2 - 7 } & Cytokines & Gene expression & Metabolome & SAB & Clinical & Final prediction \\
\hline pre-Tx & 155 & 126 & 35 & 41 & 259 & 273 \\
\hline $2 \mathrm{w}$ & 163 & 132 & 246 & 42 & 305 & 317 \\
\hline $3 \mathrm{~m}$ & 169 & 141 & 270 & 34 & 323 & 335 \\
\hline
\end{tabular}

Table 3. Number of samples employed for the prediction of eGFR-1y for every visit and marker subset, including the final prediction. For the size and composition of the marker subsets, see Table 1.The low number of pre-Tx metabolome samples is due to the low availability of pre-Tx urine samples. 


\section{Prediction of eGFR-1y with pre-transplant markers was poor,}

\section{while post-transplant panels achieved an acceptable performance}

Due to different data availability patterns, a predictor was generated for each of the five marker subsets (Table 1); the final prediction was generated through stacked generalization without imputation, using all predictors achieving a Pearson's correlation coefficient of $r>$ 0.15 between measured and predicted eGFR-1y. The predicted values of the final model at pre-Tx, $2 \mathrm{w}$ and $3 \mathrm{~m}$ are shown in Figure $2 \mathrm{~A}$. Figure $2 \mathrm{~B}$ summarizes the results achieved for each marker subset. A detailed representation of the results for each individual marker subset is shown in Figure S1. Importantly, accuracy of prediction increases with time: While the correlation of measured eGFR-1y and predicted eGFR-1y employing pre-Tx markers was poor $(\mathrm{r}=0.39)$, already at $2 \mathrm{w} r$ was 0.63 and at $3 \mathrm{~m}, \mathrm{r}=0.76$. The improvement in the prediction associated with time was important, achieving a significantly lower absolute error of the prediction (pre-Tx vs. $2 \mathrm{w}: \mathrm{P}=0.004 ; 2 \mathrm{w}$ vs. $3 \mathrm{~m}$ : $\mathrm{P}<0.001$ ).

For most marker subsets, no accurate prediction could be achieved. While the clinical subset had the highest performance of all predictors, only gene expression at pre-Tx, cytokines at $2 \mathrm{w}$ and metabolome at $3 \mathrm{~m}$ achieved a sufficient quality of prediction to be considered in the final model (see dashed boxes in Figure 2B). To better understand which individual markers are most important for prediction of eGFR-1y, we performed elastic net-based variable selection for these best-performing six predictors. The results are shown in Table S1. 

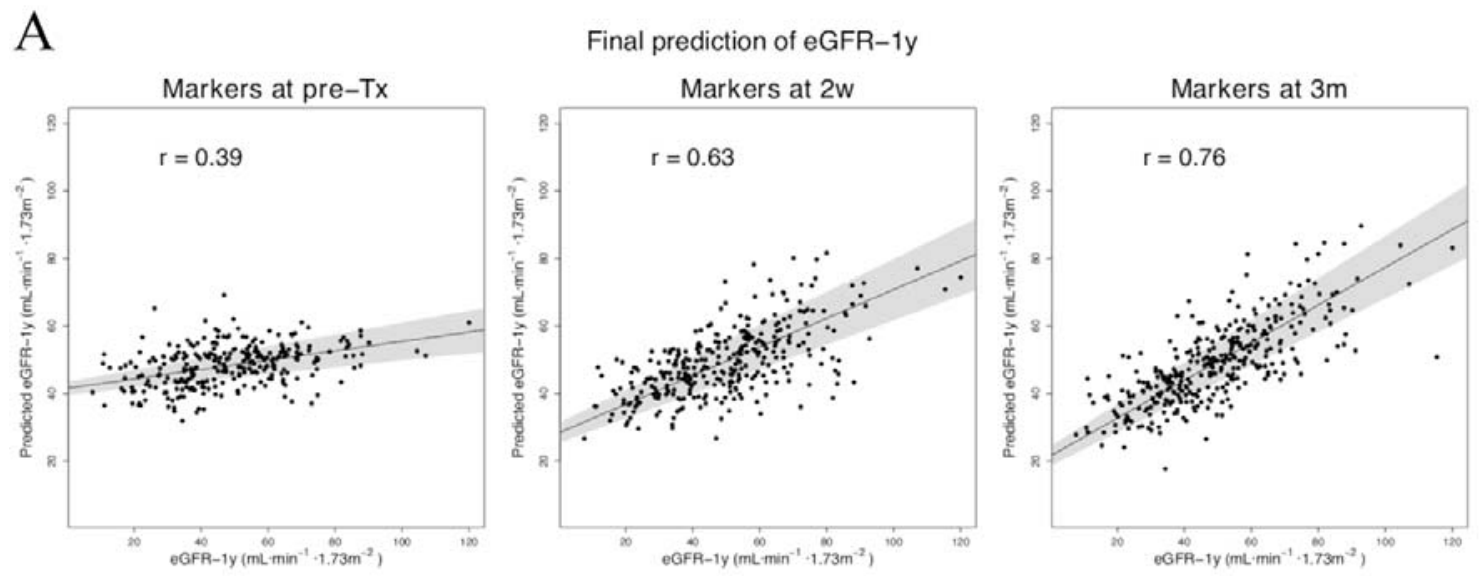

$\mathrm{B}$

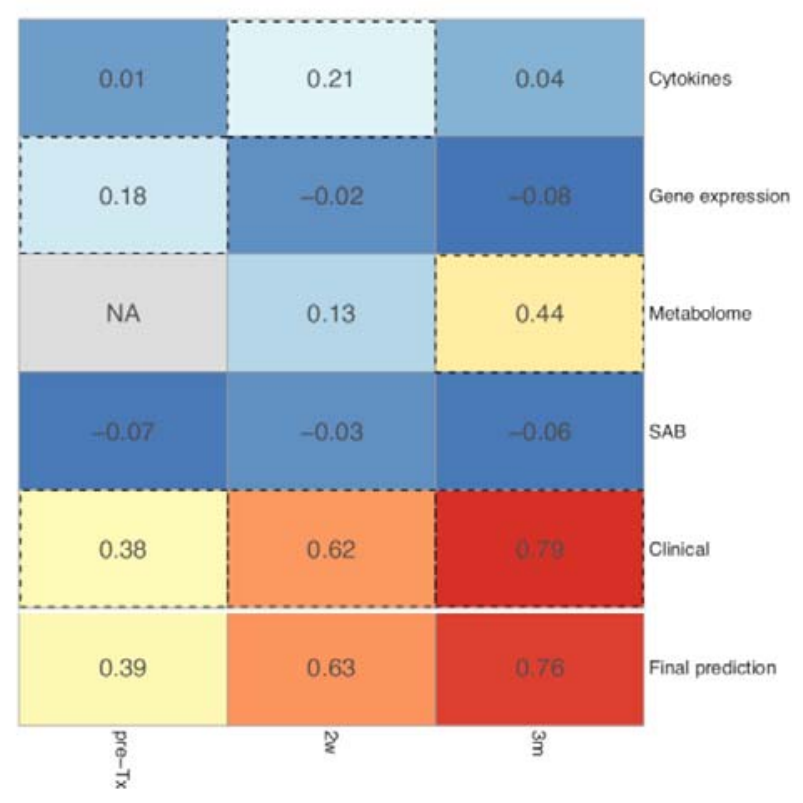

Figure 2. Summary of the prediction of eGFR-1y. (A) Predicted values of the pre-Tx, $2 \mathrm{w}$ and 3m stacked models against the experimental eGFR-1y values. (B) Summary of the correlation achieved between the predicted and measure eGFR-1y by each predictor at the three visits. The numeric value indicates the value of the Pearson correlation coefficient $r$ between the predicted and the measured eGFR-1y. Predictors achieving an $r>0.15$ were employed for the final prediction; these are highlighted with a dashed line. Note that no prediction was performed based on metabolome data pre-Tx due to the low data availability. 


\section{The pre-transplant immunological state was prognostic of eGFR-}

\section{$1 \mathbf{y}$}

We first investigated the two predictors employing pre-transplant (pre-Tx) data: the clinical and the gene expression subsets (see Table S1). For the latter, we identified a complex signature of nine genes as important markers for prediction: CD200, MAN1A1, HS3ST1, NAV3, Foxp3, TCL1A, HMMR, PNOC, and TMEM176B. For the first, we identified eight important clinical markers, comprising: age of donor and recipient, body mass index of recipient, HLA (A, B and DR) donor-recipient-mismatch, cytomegalovirus (CMV) risk constellation and, remarkably, the use of anti-CMV prophylactic strategy.

\section{Already at the second post-transplant week, eGFR was a highly precise marker for eGFR-1y}

We further investigated the prediction of eGFR based on $2 \mathrm{w}$ and $3 \mathrm{~m}$ data. For both visits, eGFR was an important marker for eGFR-1y (Figure 3).

At 2w, we also identified the recipient age, donor age and donor CMV serostatus as important markers, while for 3m, BMI and donor age were identified.

eGFR demonstrated a remarkable stability, achieving alone similar results as the complete clinical marker subset. We thus investigated whether the demographic factors provide an added value for the prediction of eGFR-1y, compared to eGFR alone. Indeed, a multiparameter regression revealed that recipient age, donor age and donor CMV serostatus at $2 \mathrm{w}$ were independently associated with eGFR-1y (recipient age: $\mathrm{P}=0.045$; donor age: $\mathrm{P}<0.001$; donor CMV serostatus: $\mathrm{P}=0.004$; eGFR-2w: $\mathrm{P}<0.001)$. Likewise, the association of donor age 
and BMI at 3m with eGFR-1y was independent from eGFR-3m (donor age: $\mathrm{P}<0.001$; BMI: $\mathrm{P}=0.008$; eGFR-3m: $\mathrm{P}<0.001)$. We therefore considered these factors to be prognostic.

Correlation of eGFR-1y with eGFR-2w and eGFR-3m
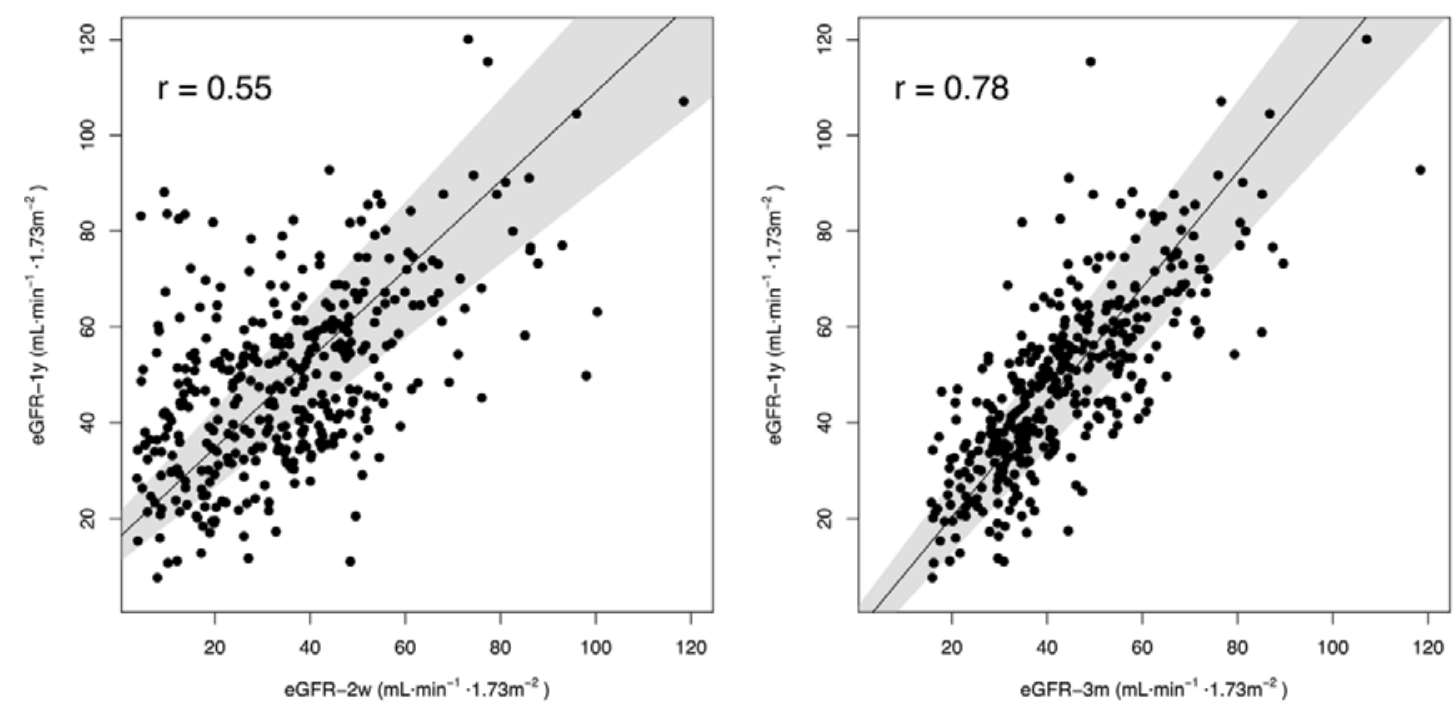

Figure 3. Correlation of eGFR-2 $w$ and eGFR-3m with eGFR-1y. The strong correlation of eGFR-2w and eGFR-3m with eGFR-1y demonstrates a high degree of stability of eGFR.

\section{Serum concentration of the stem cell factor (SCF) was negatively}

\section{correlated with renal function}

We examined the cytokine predictor at $2 \mathrm{w}$. Only one cytokine was detected as an important marker by variable selection, the stem cell factor $(\mathrm{SCF})$. SCF at $2 \mathrm{w}$ had a negative correlation with eGFR-1y (r=-0.33, P<0.001; Figure 4).

We further evaluated whether SCF is prognostic for eGFR. As SCF-2w correlated with eGFR-2w stronger than with eGFR-1y (r=-0.62, P<0.001; Figure 4), a prognostic quality of this marker seems unlikely. Furthermore, a bivariate linear regression analysis did not reveal a contribution of the cytokine on the prediction of eGFR-1y (SCF-2w: P=0.612; eGFR-2w: 
$\mathrm{P}<0.001)$. Interestingly, a correlation between SCF and eGFR was observed also at $3 \mathrm{~m}(\mathrm{r}=-$ $0.49, \mathrm{P}<0.001)$, suggesting a stable diagnostic accuracy for eGFR.

\section{Correlation of eGFR with SCF-2w}
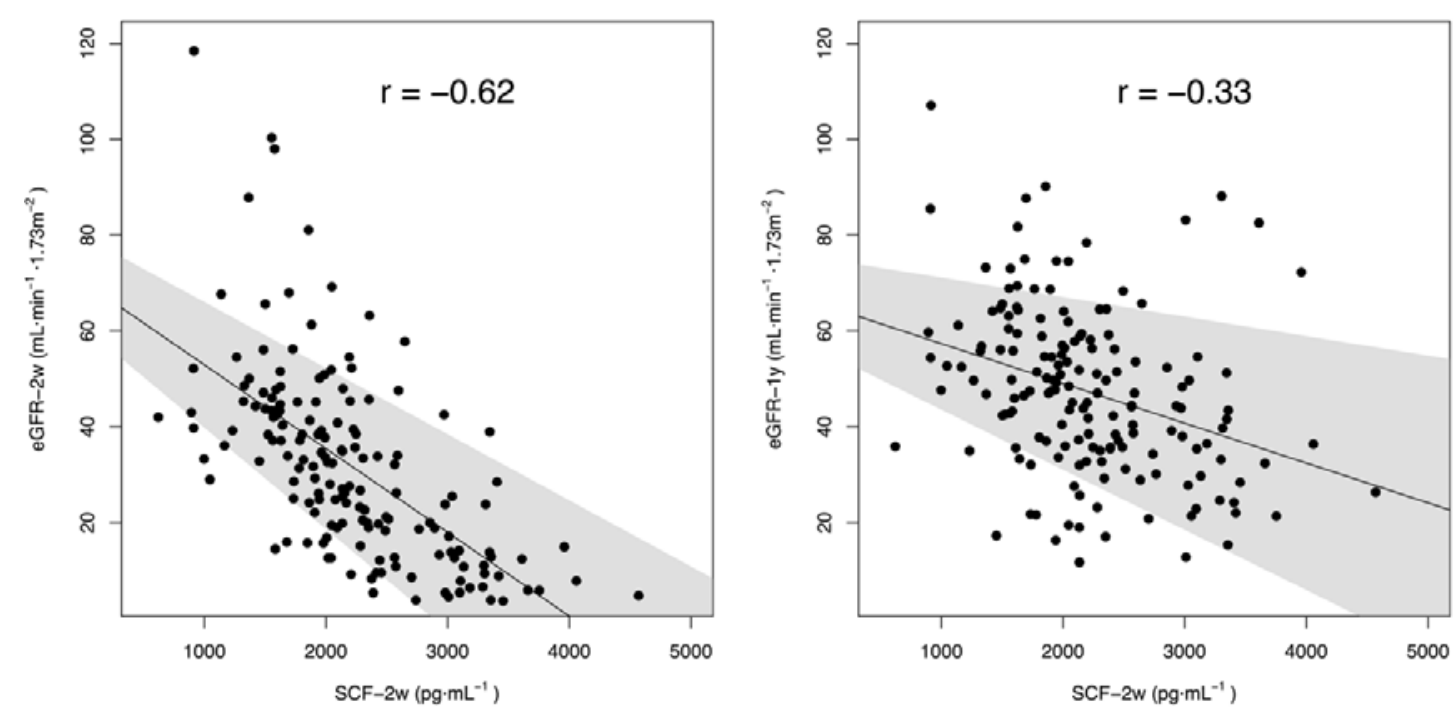

Figure 4. Correlation of eGFR with SCF-2w. Importantly, the correlation with eGFR-2w was stronger than with eGFR-1y.

\section{eGFR was associated with a urine metabolome signature}

Regarding the prediction of eGFR-1y based on the metabolome subset, a complex signature of 19 NMR bins was identified (Table S1). These NMR bins represent up to 35 metabolites, with a median of 2 [1.5-5] candidate metabolites per bin (Table S2). Interestingly, among these candidates, products of amino acid metabolism and creatinine could be found (Table S2).

The presence of creatinine suggests that the urine signature was diagnostic for eGFR-3m, rather than prognostic for eGFR-1y. As expected, a significantly improved prediction $(\mathrm{P}<0.001)$ was achieved for eGFR-3m (see Figure 5), compared to the eGFR-1y prediction. 
We furthermore analysed whether a predictive advantage for eGFR-1y could be achieved employing together eGFR-3m and metabolome markers at $3 \mathrm{~m}$. However, a bivariate linear regression analysis revealed no clear added value of the metabolome predictor, while the effect of eGFR-3m remained highly significant (Metabolome signature: $\mathrm{P}=0.097$; eGFR-3m: $\mathrm{P}<0.001)$.

\section{Prediction of eGFR based on metabolome at 3m}
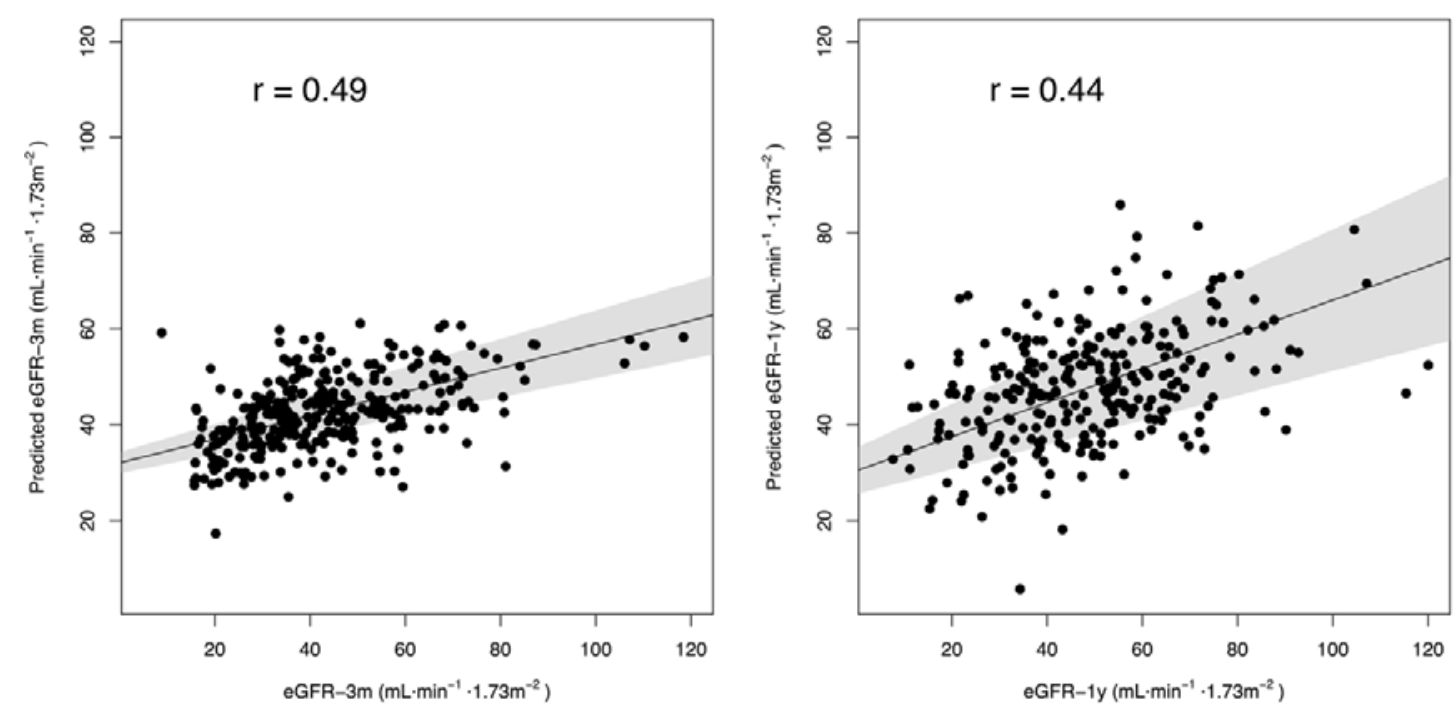

Figure 5. Prediction of eGFR employing the metabolome at $3 \mathrm{~m}$. As it can be seen, the quality of prediction achieved for eGFR-3m was higher than for eGFR-1y.

\section{TMEM176B and HMMR expression at the second post-}

\section{transplant week was prognostic for changes in eGFR}

We further investigated whether any additional prognostic markers can be found in our biomarker panel. With this goal, we repeated the analysis incorporating the eGFR at the sampling point as a variable to the cytokines, gene expression, metabolome and $\mathrm{SAB}$ subsets 
(Figure 6). While no clear improvement of the prediction capacity was achieved in comparison to the main analysis - except perhaps for the gene expression predictor - we identified two potential prognostic markers for eGFR-1y: the expression of the genes HMMR and TMEM176B.

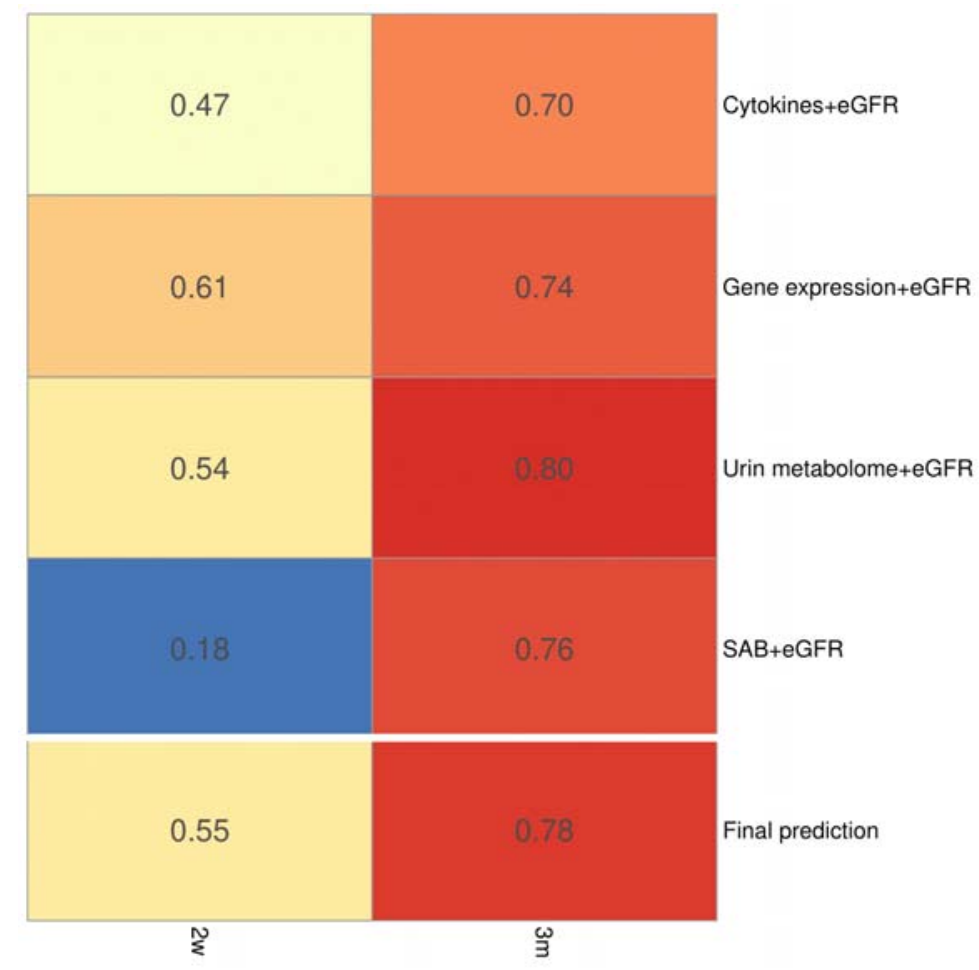

Figure 6. Summary of the analysis for prognostic eGFR-1y models. The figure depicts the correlation achieved between the predicted and measure eGFR-1y by each predictor at the three visits. Each predictor incorporates the eGFR at the time of screening as a factor; all predictors were employed for the final prediction.

High levels of HMMR and TMEM176B were associated with eGFR-1y, independently from eGFR-2w (HMMR: P=0.048; TMEM176B: P<0.001; eGFR-2w: P<0.001; Figure 7). This means that the expression of HMMR and TMEM176B is associated with changes of eGFR between $2 \mathrm{w}$ and $1 \mathrm{y}$ (see Figure 7). The observed association was not due to a potential correlation with eGFR-2w: None of the two genes showed a significant association with 
eGFR-2w employing multivariate regression analysis (HMMR: $\mathrm{P}=0.825$; TMEM176B:

$\mathrm{P}=0.057)$.
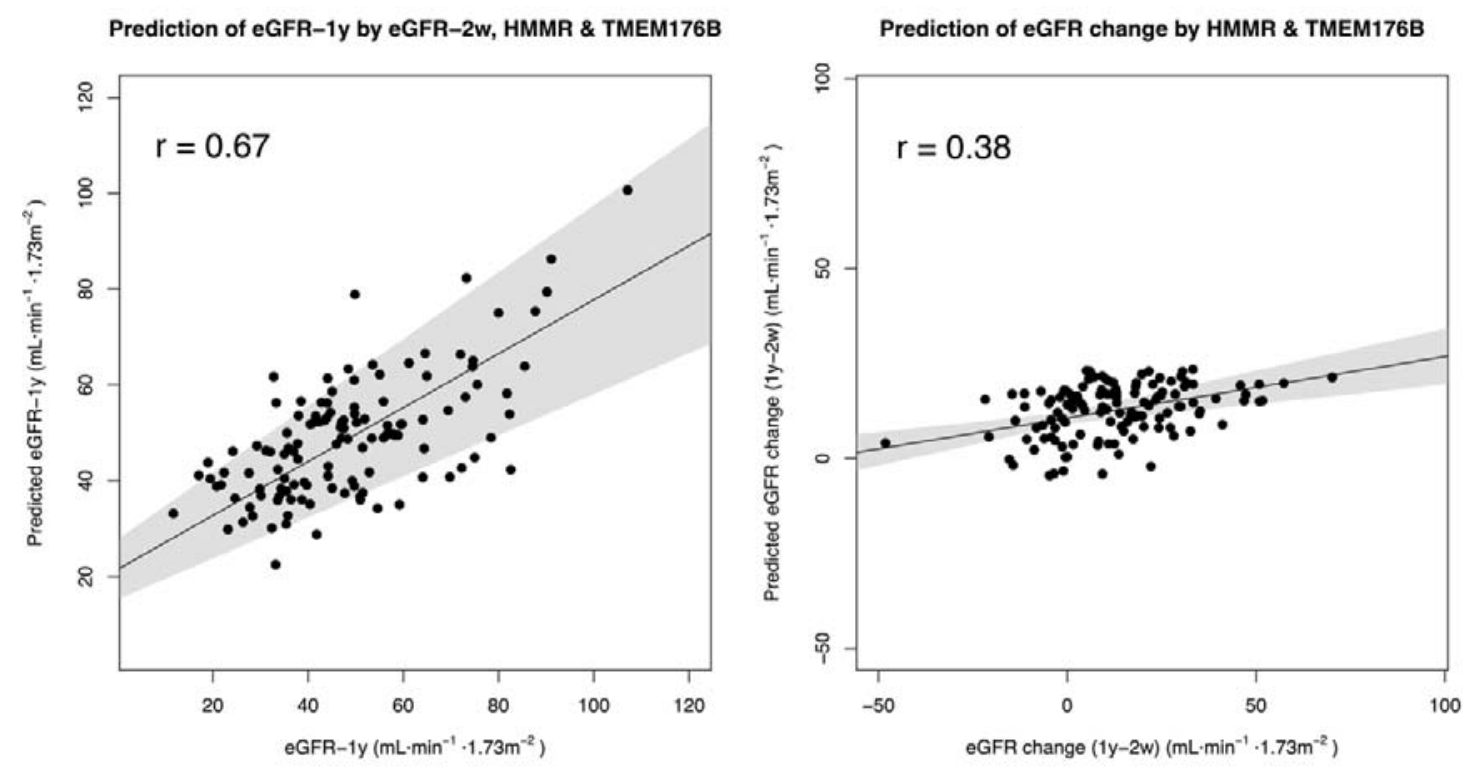

Figure 7. HMMR and TMEM176B as potential prognostic markers of eGFR. The left panel shows the prediction of eGFR-1y employing eGFR-2w, HMMR and TMEM176B. Note that the achieved correlation is higher than employing eGFR-2w alone ( $\mathrm{r}=0.55$, see Figure 5$)$. The right panel shows the prediction of eGFR change between $1 \mathrm{y}$ and $2 \mathrm{w}(\mathrm{eGFR}-1 \mathrm{y}-\mathrm{eGFR}-2 \mathrm{w})$ employing only the expression of HMMR and TMEM176B. The prediction shown in this figure was calculated by linear regression without cross-validation, due to the low number of predictors.

\section{DISCUSSION}

In this work, we have performed an in-depth characterization of a large renal transplant cohort in the pre- and early post-transplant period, with the goal of predicting transplant outcome. We have analysed the cohort of the multi-centre Harmony study at three time points using a multi-level biomarker panel, ranging from gene expression to the urine 
metabolome.[17] Employing these data, we have determined predictive models for the eGFR$1 \mathrm{y}$, identifying potential prognostic and diagnostic markers of the renal function:

- Employing pre-transplant data, the predicted value of eGFR-1y had a correlation of $\mathrm{r}=0.39$ with the measured eGFR-1y. In the post-transplant period, the quality of prediction increased to $\mathrm{r}=0.63$ (two weeks post-transplant) and $\mathrm{r}=0.76$ (three months).

- eGFR demonstrated a remarkable stability in the first post-transplant year: Posttransplant prediction was highly dependent on the value of eGFR at the corresponding time points.

- The gene expression marker subset holds eGFR-1y prognostic value. Especially the genes HMMR and TMEM176B anticipated changes in eGFR after the second posttransplant week.

- Age of donor and recipient, body mass index of recipient, donor-recipient HLA mismatch, CMV mismatch and the use of anti-CMV prophylactic strategy also demonstrated a prognostic character for eGFR-1y.

- The serum concentration of the cytokine SCF had a strong correlation with eGFR at all measured time points, but no prognostic value.

- A complex signature of the urine metabolome with potential applications for the monitoring of eGFR but no prognostic value was identified.

The data of our bio-marker panel represent a milestone in the literature of early assessment of transplant outcomes, as there exists to our knowledge no other study with a comparably profound characterization in a large patient cohort. We have achieved an acceptable predictive capacity employing data from the early post-transplant period. Our results highlight, however, the major challenge of anticipating changes in the renal function: In spite 
medRxiv preprint doi: https://doi.org/10.1101/2021.01.04.20248473; this version posted January 5, 2021. The copyright holder for this preprint (which was not certified by peer review) is the author/funder, who has granted medRxiv a license to display the preprint in perpetuity.

All rights reserved. No reuse allowed without permission.

of the large number of markers and samples characterized, we are still far from being able to predict eGFR-1y with an accuracy sufficient for clinical care.

In our results, the eGFR in the early post-transplant period was by far the most precise marker for eGFR-1y. Part of this stability of eGFR can be explained by the nature of our transplant cohort, with low immunological risk and reduced adverse events.[17] This stability is in line with the literature from the last two decades, highlighting that the challenge of posttransplant risk assessment is to anticipate the rare negative changes in eGFR.[36-38]

Here, the most promising markers for eGFR changes belong to the gene expression panel. In the second post-transplant week, the expression of the genes HMMR and TMEM176B anticipated significantly eGFR drops. This observation is coherent with the literature: HMMR is upregulated in lymphocytes during acute rejection in rat.[26] In humans, a study on psoriasis has found a significant association between HMMR and response to immunosuppression.[24] On the other hand, the expression of TMEM176B in peripheral blood is known to be associated with acute rejection in humans.[27] Based on this evidence, we hypothesize that increased expression levels of the genes are a symptom of insufficient immunosuppression, leading to graft inflammation and decrease of eGFR.

Regarding further prognostic markers, the results of our pre-transplant clinical predictor are in basic agreement with the previous work by Lasserre et al.[6] Their work supports the generalizability of our results, as all of the markers identified as important for our predictor were employed in their work for prediction.[6]

We found evidence of an association of eGFR with the cytokine SCF and the urine metabolomic profile. While these associations did not have a prognostic character, i.e. they are markers of eGFR at the time of monitoring, they might still be of interest for achieving a more profound understanding and improved monitoring of eGFR. Thus, there was a strong 
medRxiv preprint doi: https://doi.org/10.1101/2021.01.04.20248473; this version posted January 5, 2021. The copyright holder for this preprint (which was not certified by peer review) is the author/funder, who has granted medRxiv a license to display the preprint in perpetuity.

All rights reserved. No reuse allowed without permission.

negative correlation of SCF serum levels with eGFR. An association between SCF and renal function has been observed repeatedly in other contexts.[39-42] Experiments in rat offer a potential cause, suggesting an association of SCF expression with renal fibrosis.[43]

Regarding the urine metabolomic profile, our study is a step within current efforts towards a non-invasive monitoring of renal function.[22,44-46] Our preliminary analysis suggests a role of urinary creatinine and amino acid metabolism in the prediction. This is in agreement with the results of Posada-Ayala et al. on markers for chronic kidney disease.[46] Importantly, further research is needed for a reduction of the number of candidate metabolites of our signature, to develop a non-invasive renal function monitoring assay.

Our study has some limitations. Firstly, eGFR is only an approximation of the renal function.[21] Ideally, the end-point of a predictive model should be measured directly, employing a gold standard method.[47] Secondly, the composition of the cohort is not representative for the clinical reality, as only patients with low immunological risk were admitted into the study.[17] Thirdly, the study design makes it especially sensitive to survivor bias, as only patients with a (at least partially) functional graft one year post-transplant are evaluated. This is important, since the characterized patients had significantly higher renal function two weeks post-transplant than those lost to follow-up. Finally, not all patients could be characterized for each marker subset, due to issues of sample availability. While the employed modelling approach works well with the different data availabilities for each marker subset, an increased data availability could have allowed for a more accurate modelling of eGFR-1y and identification of potential markers.

In summary, we present the results of an unprecedented characterization of a large renal transplant cohort during the pre-transplant and early post-transplant period, with the goal of predicting the outcome eGFR-1y. Our results highlight the stability of renal function and the 
medRxiv preprint doi: https://doi.org/10.1101/2021.01.04.20248473; this version posted January 5, 2021. The copyright holder for this preprint

(which was not certified by peer review) is the author/funder, who has granted medRxiv a license to display the preprint in perpetuity.

All rights reserved. No reuse allowed without permission.

difficulty of predicting abrupt changes. They provide two novel candidates for prognostic markers - the expression of the genes HMMR and TMEM176B. Furthermore, we have provided new evidence on the association between renal function and the cytokine SCF and identified a metabolomic signature in urine with potential applications in non-invasive monitoring. Finally, we have achieved an acceptable accuracy in the prediction of transplant outcome, although our capacity to predict abrupt changes in the eGFR still insufficient for a direct application in the clinical context. 


\section{CONFLICT OF INTEREST STATEMENT}

The authors have no conflicts of interest to disclose

\section{FUNDING AND ACKNOWLEDGEMENTS}

This work was funded by the German Federal Ministry of Education and Research (BMBF), project e:KID (01ZX1312). The funders had no role in data collection, data analysis, data interpretation, writing of the manuscript, or manuscript submission. 


\section{REFERENCES}

1. Hart A, Smith JM, Skeans MA, et al. OPTN / SRTR 2016 Annual Data Report Kidney. Am J Transplant. 2018;(Suppl 1):18-113. doi:10.1111/ajt.14557

2. Wekerle T, Segev D, Lechler R, Oberbauer R. Strategies for long-term preservation of kidney graft function. Lancet. 2017;389:2152-2162. doi:10.1016/S0140$6736(17) 31283-7$

3. Dunn TB, Noreen H, Gillingham K, et al. Revisiting traditional risk factors for rejection and graft loss after kidney transplantation. Am J Transplant. 2011;11:2132-2143. doi:10.1111/j.1600-6143.2011.03640.x

4. Moore J, He X, Shabir S, et al. Development and evaluation of a composite risk score to predict kidney transplant failure. Am J Kidney Dis. 2011;57(5):744-751. doi:10.1053/j.ajkd.2010.12.017

5. Elbadri A, Traynor C, Veitch JT, et al. Factors affecting eGFR 5-year post-deceased donor renal transplant: Analysis and predictive model. Ren Fail. 2015;37(3):417-423. doi:10.3109/0886022X.2014.1001304

6. Lasserre J, Arnold S, Vingron M, Reinke P, Hinrichs C. Predicting the outcome of renal transplantation. J Am Med Informatics Assoc. 2012;19(2):255-262. doi:10.1136/amiajnl-2010-000004

7. Ahmed K, Ahmad N, Khan MS, et al. Influence of Number of Retransplants on Renal Graft Outcome. Transplant Proc. 2008;40(5):1349-1352.

doi:10.1016/j.transproceed.2008.03.144

8. Legendre C, Canaud G, Martinez F. Factors influencing long-term outcome after kidney transplantation. Transpl Int. 2014;27(1):19-27. doi:10.1111/tri.12217

9. Senanayake S, White N, Graves N, Healy H, Baboolal K, Kularatna S. Machine learning in predicting graft failure following kidney transplantation: A systematic review 
medRxiv preprint doi: https://doi.org/10.1101/2021.01.04.20248473; this version posted January 5, 2021. The copyright holder for this preprint (which was not certified by peer review) is the author/funder, who has granted medRxiv a license to display the preprint in perpetuity.

All rights reserved. No reuse allowed without permission.

of published predictive models. Int J Med Inform. 2019;130(March):103957.

doi:10.1016/j.jijmedinf.2019.103957

10. Wittenbrink N, Herrmann S, Blazquez-Navarro A, et al. A novel approach reveals that

HLA class 1 single antigen bead-signatures provide a means of high-accuracy pretransplant risk assessment of acute cellular rejection. BMC Immunol. 2019;20:11. doi:https://doi.org/10.1186/s12865-019-0291-2

11. Mancebo E, Castro MJ, Allende LM, et al. High proportion of CD95+ and CD38+ in cultured CD8+ T cells predicts acute rejection and infection, respectively, in kidney recipients. Transpl Immunol. 2016;34:33-41. doi:10.1016/j.trim.2016.01.001

12. Malheiro J, Tafulo S, Dias L, et al. Analysis of preformed donor-specific anti-HLA antibodies characteristics for prediction of antibody-mediated rejection in kidney transplantation. Transpl Immunol. 2015;32:66-71. doi:10.1016/j.trim.2015.01.002

13. Salvadé I, Aubert V, Venetz JP, et al. Clinically-relevant threshold of preformed donorspecific anti-HLA antibodies in kidney transplantation. Hum Immunol. 2016;77:483489. doi:10.1016/j.humimm.2016.04.010

14. Shaikhina T, Lowe D, Daga S, Briggs D, Higgins R, Khovanova N. Decision tree and random forest models for outcome prediction in antibody incompatible kidney transplantation. Biomed Signal Process Control. 2017. doi:10.1016/j.bspc.2017.01.012

15. Becker LE, Morath C, Suesal C. Immune mechanisms of acute and chronic rejection. Clin Biochem. 2016;49:320-323. doi:10.1016/j.clinbiochem.2016.02.001

16. Suthanthiran M, Schwartz JE, Ding R, et al. Urinary-Cell mRNA Profile and Acute Cellular Rejection in Kidney Allografts. N Engl J Med. 2013;369(1):20-31. doi:10.1056/NEJMoa1215555

17. Thomusch O, Wiesener M, Opgenoorth M, et al. Rabbit-ATG or basiliximab induction for rapid steroid withdrawal after renal transplantation (Harmony): an open-label, multicentre, randomised controlled trial. Lancet. 2016;388:3006-3016.

doi:10.1016/S0140-6736(16)32187-0 
medRxiv preprint doi: https://doi.org/10.1101/2021.01.04.20248473; this version posted January 5, 2021. The copyright holder for this preprint (which was not certified by peer review) is the author/funder, who has granted medRxiv a license to display the preprint in perpetuity.

All rights reserved. No reuse allowed without permission.

18. Salvadori M, Rosati A, Bock A, et al. Estimated one-year glomerular filtration rate is the best predictor of long-term graft function following renal transplant.

Transplantation. 2006;81(2):202-206. doi:10.1097/01.tp.0000188135.04259.2e

19. Faddoul G, Nadkarni GN, Bridges ND, et al. Analysis of biomarkers within the initial 2 years posttransplant and 5-year kidney transplant outcomes: Results from clinical trials in organ transplantation-17. Transplantation. 2018;102(4):673-680.

doi:10.1097/TP.0000000000002026

20. Resende L, Guerra J, Santana A, Mil-Homens C, Abreu F, da Costa AG. First Year Renal Function as a Predictor of Kidney Allograft Outcome. Transplant Proc.

2009;41(3):846-848. doi:10.1016/j.transproceed.2009.01.066

21. Levey AS, Stevens LA, Schmid $\mathrm{CH}$, et al. A new equation to estimate glomerular filtration rate. Ann Intern Med. 2009;150(9):604-612. doi:10.7326/0003-4819-150-9200905050-00006

22. Banas M, Neumann S, Eiglsperger J, et al. Identification of a urine metabolite constellation characteristic for kidney allograft rejection. Metabolomics. 2018;14:116. doi:10.1007/s11306-018-1419-8

23. Sawitzki B, Schlickeiser S, Reinke P, Volk H-D. Monitoring tolerance and rejection in organ transplant recipients. Biomarkers. 2011;16(sup1):S42-S50.

doi:10.3109/1354750X.2011.578754

24. Keeren K, Friedrich M, Gebuhr I, et al. Expression of Tolerance Associated Gene-1, a Mitochondrial Protein Inhibiting T Cell Activation, Can Be Used to Predict Response to Immune Modulating Therapies. J Immunol. 2009;183(6):4077-4087.

doi:10.4049/jimmunol.0804351

25. Sagoo P, Perucha E, Sawitzki B, et al. Development of a cross-platform biomarker signature to detect renal transplant tolerance in humans. J Clin Invest. 2010;120(6):1848-1861. doi:10.1172/JCI39922

26. Sawitzki B, Bushell A, Steger U, et al. Identification of gene markers for the prediction of allograft rejection or permanent acceptance. Am J Transplant. 2007;7(5):1091- 
medRxiv preprint doi: https://doi.org/10.1101/2021.01.04.20248473; this version posted January 5, 2021. The copyright holder for this preprint (which was not certified by peer review) is the author/funder, who has granted medRxiv a license to display the preprint in perpetuity.

All rights reserved. No reuse allowed without permission.

1102. doi:10.1111/j.1600-6143.2007.01768.x

27. Viklicky O, Krystufkova E, Brabcova I, et al. B-cell-related biomarkers of tolerance are up-regulated in rejection-free kidney transplant recipients. Transplantation.

2013;95(1):148-154. doi:10.1097/TP.0b013e3182789a24

28. Krepsova E, Tycova I, Sekerkova A, et al. Effect of induction therapy on the expression of molecular markers associated with rejection and tolerance. BMC Nephrol. 2015;16(1):1-9. doi:10.1186/s12882-015-0141-2

29. Blazquez-Navarro A, Dang-Heine C, Bauer C, et al. Sex-associated differences in cytomegalovirus prevention: Prophylactic strategy is potentially associated with a strong kidney function impairment in female renal transplant patients. Front Pharmacol. 2020. doi:10.3389/fphar.2020.534681

30. Blazquez-Navarro A, Dang-Heine C, Wittenbrink N, et al. BKV, CMV, and EBV Interactions and their Effect on Graft Function One Year Post-Renal Transplantation: Results from a Large Multi-Centre Study. EBioMedicine. 2018;34:113-121. doi:10.1016/j.ebiom.2018.07.017

31. R Core Team, R Development Core Team. R: A language and environment for statistical computing. 2019. http://www.r-project.org/.

32. Ghaemi MS, DiGiulio DB, Contrepois K, et al. Multiomics modeling of the immunome, transcriptome, microbiome, proteome and metabolome adaptations during human pregnancy. Bioinformatics. 2019;35(1):95-103. doi:10.1093/bioinformatics/bty537

33. van Buuren S, Groothuis-Oudshoorn K. \{mice\}: Multivariate Imputation by Chained Equations in R. J Stat Softw. 2011;45(3):1-67. https://www.jstatsoft.org/v45/i03/.

34. Friedman J, Hastie T, Tibshirani R. Regularization Paths for Generalized Linear Models via Coordinate Descent. J Stat Softw. 2010;33(1):1-22.

doi:10.1016/j.expneurol.2008.01.011

35. Microsoft, Ooi H. glmnetUtils: Utilities for "Glmnet." 2020. https://cran.rproject.org/package=glmnetUtils.

36. Gourishankar S, Hunsicker LG, Jhangri GS, Cockfield SM, Halloran PF. The stability 
medRxiv preprint doi: https://doi.org/10.1101/2021.01.04.20248473; this version posted January 5, 2021. The copyright holder for this preprint (which was not certified by peer review) is the author/funder, who has granted medRxiv a license to display the preprint in perpetuity.

All rights reserved. No reuse allowed without permission.

of the glomerular filtration rate after renal transplantation is improving. $J$ Am Soc Nephrol. 2003;14(9):2387-2394. doi:10.1097/01.ASN.0000085019.95339.F0

37. Clayton PA, Lim WH, Wong G, Chadban SJ. Relationship between eGFR decline and hard outcomes after kidney transplants. J Am Soc Nephrol. 2016;27(11):3440-3446. doi:10.1681/ASN.2015050524

38. Atay FF, Taskapan H, Berktas B, Yildirim O, Dogan M, Piskin T. Factors Affecting eGFR Slope of Renal Transplant Patients During the First 2 Years. Transplant Proc. 2019;51(7):2318-2320. doi:https://doi.org/10.1016/j.transproceed.2019.01.165

39. Kitoh $\mathrm{T}$, Ishikawa $\mathrm{H}$, Ishii $\mathrm{T}$, Nakagawa S. Elevated SCF levels in the serum of patients with chronic renal failure. Br J Haematol. 1998;102(5):1151-1156. doi:10.1046/j.1365-2141.1998.00902.x

40. Zhang W, Jia L, Liu DLX, et al. Serum Stem Cell Factor Level Predicts Decline in Kidney Function in Healthy Aging Adults. J Nutr Heal Aging. 2019;23(9):813-820. doi:10.1007/s12603-019-1253-3

41. Alachkar N, Ugarte R, Huang E, et al. Stem cell factor, interleukin-16, and interleukin2 receptor alpha are predictive biomarkers for delayed and slow graft function.

Transplant Proc. 2010;42(9):3399-3405. doi:10.1016/j.transproceed.2010.06.013

42. El Kossi MMH, EI Nahas AM. Stem cell factor and crescentic glomerulonephritis. Am J Kidney Dis. 2003;41(4):785-795. doi:https://doi.org/10.1016/S0272-6386(03)00026-X

43. Li Y, Zhou L, Liu F, et al. Mast cell infiltration is involved in renal interstitial fibrosis in a rat model of protein-overload nephropathy. Kidney Blood Press Res. 2010;33(3):240248. doi:10.1159/000317102

44. Nkuipou-Kenfack E, Duranton F, Gayrard N, et al. Assessment of metabolomic and proteomic biomarkers in detection and prognosis of progression of renal function in chronic kidney disease. PLoS One. 2014;9(5). doi:10.1371/journal.pone.0096955

45. Ng DPK, Salim A, Liu Y, et al. A metabolomic study of low estimated GFR in nonproteinuric type 2 diabetes mellitus. Diabetologia. 2012;55(2):499-508.

doi:10.1007/s00125-011-2339-6 
medRxiv preprint doi: https://doi.org/10.1101/2021.01.04.20248473; this version posted January 5, 2021. The copyright holder for this preprint (which was not certified by peer review) is the author/funder, who has granted medRxiv a license to display the preprint in perpetuity. All rights reserved. No reuse allowed without permission.

46. Posada-Ayala M, Zubiri I, Martin-Lorenzo M, et al. Identification of a urine metabolomic signature in patients with advanced-stage chronic kidney disease.

Kidney Int. 2014;85(1):103-111. doi:10.1038/ki.2013.328

47. Michels WM, Grootendorst DC, Verduijn M, Elliott EG, Dekker FW, Krediet RT.

Performance of the Cockcroft-Gault, MDRD, and new CKD-EPI formulas in relation to GFR, age, and body size. Clin J Am Soc Nephrol. 2010;5:1003-1009.

doi:10.2215/CJN.06870909 


\section{SUPPLEMENTARY MATERIALS}

\section{Supplementary Methods.}

Table S1: Results of the variable selection for all subsets achieving a prediction with $r>0.15$.

The table shows the name of all markers selected through variable selection, as well as the subset and visit they belong to, their importance in the prediction and the nature of their association with eGFR-1y. The importance is calculated as the percentage of cross-validation iterations for which the marker was considered in the regression. Only markers achieving an importance over $20 \%$ are listed here.

Table S2: Description of the bins (metabolome at 3m) important for the prediction of eGFR1y and identification of the candidate molecules for these bins.

Figure S1: Detailed results of the prediction of eGFR-1y for every marker subset and visit. The correlation achieved between the predicted and measure eGFR-1y by each predictor is shown. The numeric value indicates the value of the Pearson correlation for the predicted and the measured eGFR-1y. 